\title{
Kualitas Pelayanan Berpengaruh terhadap Loyalitas Pasien Rumah Sakit
}

\author{
Nurul Romadhona, ${ }^{1}$ Muhardi, ${ }^{2}$ Nirmala Kesumah ${ }^{3}$ \\ ${ }^{1}$ Departemen Ilmu Kesehatan Masyarakat Fakultas Kedokteran Universitas Islam Bandung \\ ${ }^{2}$ Program Studi Ilmu Ekonomi Universitas Islam Bandung \\ ${ }_{3}^{3}$ Klinik Teratai Rumah Sakit Hasan Sadikin Bandung
}

\begin{abstract}
Abstrak
Banyaknya rumah sakit di Indonesia menimbulkan persaingan ketat sehingga perlu memberikan pelayanan kesehatan yang berkualitas. Kualitas menciptakan persepsi positif pasien terhadap rumah sakit sehingga menghasilkan kepuasan serta loyalitas pasien. Tujuan penelitian ini mengetahui pengaruh kualitas pelayanan terhadap loyalitas pasien. Penelitian dilakukan tahun 2011 di Poliklinik Rumah Sakit X Bandung. Metode penelitian ini adalah deskriptif analitik menggunakan desain cross sectional terhadap sampel 100 orang. Teknik pengambilan sampel adalah consecutive sampling. Variabel bebas, yaitu kualitas pelayanan dengan dimensi keandalan, ketanggapan, jaminan, empati, dan bukti fisik, sedangkan variabel terikat adalah loyalitas pasien. Instrumen penelitian ini adalah kuesioner yang telah diuji validitas dan realibilitasnya. Penelitian ini menggunakan uji parsial (uji t), uji serempak (uji f), dan uji koefisien determinasi $\left(\mathrm{R}^{2}\right)$. Hasil uji t dimensi keandalan, ketanggapan, jaminan, dan empati diperoleh tingkat signifikansi $=0,000$; sedangkan berwujud $=0,027, \alpha=5 \%$, berarti kelima dimensi secara parsial berpengaruh signifikan terhadap loyalitas pasien. Hasil uji f diperoleh tingkat signifikansi $=0,000$, $\alpha=5 \%$, berarti kelima dimensi secara bersama-sama berpengaruh signifikan terhadap loyalitas pasien. Hasil uji koefisien determinasi diperoleh nilai $\mathrm{R}^{2}=0,855$, berarti kontribusi kualitas pelayanan terhadap loyalitas sebesar 85,5\%. Faktor penentu loyalitas pasien adalah kualitas pelayanan, input, dan hasil pelayanan yang diberikan kepada pasien. Simpulan kualitas pelayangan berpengaruh terhadap loyalitas pasien.
\end{abstract}

Kata kunci: Kualitas pelayanan, loyalitas pasien, rumah sakit

\section{The Quality of Service Influences the Loyalty of Hospital Patients}

\begin{abstract}
A large number of hospitals in Indonesia cause fierce competition, so it is necessary to provide quality health services. Quality creates a positive perception of patients towards hospitals that results in patient satisfaction and loyalty. The purpose of this study was to determine the effect of service quality on patient loyalty. The study was conducted in 2011 at the X Polyclinic Hospital in Bandung. The method of this research is descriptive analytic, using a cross sectional design, a sample of 100 people. The sampling technique was consecutive sampling. The independent variable was the quality of service with dimensions of reliability, responsiveness, assurance, empathy, and tangibles, while the dependent variable was patient loyalty. The instrument of this research is a questionnaire that has been tested for validity and reliability. This study used a partial test ( $t$ test), simultaneous test ( $\mathrm{f}$ test), and coefficient of determination test (R2). The t test result of reliability, responsiveness, assurance, and empathy dimensions obtained a significance level $=0.000$; while tangible $=0.027, \alpha=5 \%$, meaning that the five dimensions partially have a significant effect on patient loyalty. The f test results obtained a significance level $=0.000, \alpha=$ $5 \%$, meaning that the five dimensions togetherly had a significant effect on patient loyalty. The test results of the coefficient of determination obtained the value of $\mathrm{R} 2=0.855$, meaning that the contribution of service quality to loyalty was $85.5 \%$. In correlasion determinants of patient loyalty are service quality, input, and results of services provided to patients. In conclusion the quality of service affects patient loyalty.
\end{abstract}

Keywords: Hospital, patient loyalty, service quality

Korespondensi: Nurul Romadhona. Departemen Ilmu Kesehatan Masyarakat, Fakultas Kedokteran, Universitas Islam Bandung, Jalan Taman Sari No. 22, 40116, Kota Bandung, Provinsi Jawa Barat, Email: nurulromadhonadokter@gmail.com 


\section{Pendahuluan}

Saat ini dunia telah memasuki era globalisasi di berbagai bidang, termasuk jasa. Di Indonesia, sektor jasa sendiri berkembang dengan pesat. Salah satu contohnya adalah jasa kesehatan. Banyak produk jasa kesehatan yang tersedia, misalnya adalah rumah sakit. Dilihat dari segi pertumbuhan, belakangan ini, jumlah rumah sakit semakin banyak, terutama di kotakota besar. Hal ini akan menimbulkan tantangan bagi manajemen rumah sakit baik pemilik maupun pengelola agar rumah sakitnya mampu bersaing dan bertahan di dalam sektor jasa kesehatan.

Upaya yang harus dilakukan rumah sakit untuk dapat bertahan dan berkembang adalah dengan meningkatkan pendapatan rumah sakit yang berasal dari pasien baik langsung maupun tidak langsung, misalnya asuransi kesehatan. Hal ini dapat dilihat dari jumlah kunjungan pasien. Peningkatan jumlah kunjungan pasien dapat diupayakan oleh rumah sakit dengan menyajikan dan memberikan pelayanan kesehatan yang berkualitas. ${ }^{1 "}$

Terdapat beberapa dimensi kualitas pelayanan menurut Kotler. Pertama, keandalan, yaitu kemampuan melaksanakan jasa atau pelayanan dengan andal. Kedua, responsivitas, yaitu kemampuan memberikan pelayanan dengan tepat waktu. Ketiga, jaminan berupa kemampuan personil rumah sakit dalam memberikan kepercayaan dan keyakinan kepada pasien. Keempat, empati berupa kemampuan memberikan perhatian kepada pasien. Terakhir, bukti fisik berupa fasilitas yang ditampilkan. ${ }^{2}$

Terdapat beberapa pelayanan yang disediakan oleh rumah sakit, yaitu pelayanan rawat inap, rawat jalan misalnya poliklinik, dan lain-lain. Kini, pelayanan rawat jalan menjadi sumber pendapatan yang dapat menyaingi pendapatan rawat inap karena jumlah kunjungan pasien yang lebih banyak. Selain itu, pemilihan rawat inap oleh pasien biasanya berasal dari rawat jalan.

Terdapat beberapa kategori pasien di dalam rumah sakit, yaitu pasien baru dan lama. Kunjungan pasien baru ke sebuah rumah sakit mencerminkan minat pasien saat ini untuk menggunakan pelayanan, sedangkan kunjungan pasien lama mencerminkan loyalitas pasien. Salah satu ciri pasien loyal adalah melakukan pembelian atau juga pemanfaatan ulang dari suatu pelayanan. Semakin tinggi frekuensi pemanfaatan ulang suatu pelayanan oleh pasien maka mencerminkan semakin loyal pasien tersebut. ${ }^{3}$

Loyalitas merupakan kesediaan pasien untuk terus memanfaatkan kembali pelayanan rumah sakit dalam jangka panjang dan dengan suka rela merekomendasikan rumah sakit tersebut kepada keluarga dan atau teman-temannya. ${ }^{3}$ Faktor yang dapat meningkatkan loyalitas adalah tingkat kepuasan pasien. ${ }^{4}$ Kepuasan adalah perasaan pasien setelah menerima pelayanan yang sesuai dengan harapannya. ${ }^{5}$ Faktor utama sebagai penentu kepuasan pasien adalah persepsinya terhadap kualitas pelayanan rumah sakit. Jadi, rumah sakit yang memberikan pelayanan yang berkualitas dapat menimbulkan kepuasan bagi pasien sehingga terciptalah tujuan yang diharapkan oleh rumah sakit, yaitu loyalitas pasien. ${ }^{4}$

\section{Metode}

Penelitian ini dilakukan di Poliklinik Rumah Sakit X di Bandung pada tahun 2011. Merupakan penelitian deskriptif analitik dengan desain cross sectional. Teknik pengambilan sampel penelitian dengan metode consecutive sampling. ${ }^{6}$ Jumlah sampel diperhitungkan dengan menggunakan rumus Slovin dan didapatkan 100 orang.

Variabel bebas, yaitu kualitas pelayanan yang terdiri atas dimensi keandalan, ketanggapan, jaminan, empati dan berwujud, sedangkan variabel terikatnya adalah loyalitas pasien. Instrumen penelitian ini adalah kuesioner yang telah diuji validitas dan realibilitasnya. Kuesioner terdiri atas 30 pernyataan berupa 25 pernyataan mengenai lima dimensi kualitas pelayanan (dimensi masing-masing lima pernyataan) dan lima pernyataan mengenai loyalitas pelayanan. Tiaptiap pernyataan disertai lima kemungkinan jawaban tertutup model Skala Likert (Likert's summated ratings/LSR), yaitu sangat setuju, setuju, ragu-ragu, tidak setuju, dan sangat tidak setuju yang harus dipilih oleh responden. Analisis penelitian ini menggunakan uji parsial (uji t), uji serempak (uji f), dan uji koefisien determinasi $\left(\mathrm{R}^{2}\right)$.

\section{Hasil}

Berikut ini merupakan hasil penelitian mengenai lima dimensi kualitas pelayanan yang digambarkan pada Tabel 1 dan 2.

Untuk mengetahui tingkatan menurut penilaian responden dapat dilihat dari tahapan berikut ini, skor maksimal $=5 \times 5$ item $\times 100$ responden $=2.500$ skor minimal $=1 \times 5$ item $\times 100$ responden $=500$ rentang $=$ $2.500-500=2.000$ panjang interval $=2.000 / 5=400$.

Total skor minimal tiap-tiap dimensi variabel kualitas pelayanan adalah 500 dan maksimal 2.500. Tingkatan penilaiannya adalah skor tidak baik 500900, kurang baik 901-1.300, cukup baik 1.301-1.700, baik 1.701-2.100, dan sangat baik 2.101-2.500. Total skor hasil penelitian dimensi keandalan (reliability) sebesar 1.914, ketanggapan 1.880, jaminan 2.066, empati 1.909, dan bukti fisik 1.914 sehingga dapat disimpulkan bahwa penilaian pasien terhadap rumah sakit dari kelima dimensi tersebut adalah baik.

Untuk mengetahui tingkatan menurut penilian responden dapat dilihat berdasar diagram tahapan kuartil berikut ini, skor maksimal $=5 \times 25$ item $\times 100$ responden $=1.2500$ skor minimal $=1 \times 25$ item $\times 100$ responden $=2.500$ rentang $=12.500-2.500=10.000$ panjang interval $=10.000 / 5=2.000$.

Tingkatan penilaian variabel kualitas pelayanan rumah sakit oleh responden adalah skor tidak baik 2.500-4.500, kurang baik 4.501-6.500, cukup baik 6.501-8.500, baik 8501-10500, dan sangat baik 10.501-12.500. Total skor hasil penelitian variabel kualitas pelayanan Rumah Sakit X sebesar 9.688 sehingga dapat disimpulkan bahwa kualitas pelayanan Rumah Sakit X adalah baik.

Berikut ini merupakan hasil penelitian mengenai variabel loyalitas pasien yang digambarkan pada Tabel 3 . 
Tabel 1 Persentase dan Total Skor Tiap-tiap Dimensi Variabel Kualitas Pelayanan

\begin{tabular}{|c|c|c|c|}
\hline $\begin{array}{l}\text { No } \\
\text { Item }\end{array}$ & Pernyataan & Skor Total & Persentase \\
\hline & Dimensi Keandalan & & \\
\hline 1 & Dokter hadir tepat waktu. & 362 & 18,91 \\
\hline 2 & Diagnosis dokter terbukti akurat. & 399 & 20,85 \\
\hline 3 & $\begin{array}{l}\text { Staf administrasi melakukan prosedur penerimaan pasien } \\
\text { dengan mudah. }\end{array}$ & 368 & 19,22 \\
\hline 4 & Jika berjanji, dokter menepatinya. & 393 & 20,53 \\
\hline 5 & Perawat andal melakukan tugasnya. & 392 & 20,48 \\
\hline 6 & $\begin{array}{l}\text { Dimensi Ketanggapan } \\
\text { Untuk mendapat giliran diperiksa dokter, saya tidak harus } \\
\text { menunggu lama. }\end{array}$ & 318 & 16,91 \\
\hline 7 & Dokter cepat tanggap dalam memberikan pelayanan. & 395 & 21,01 \\
\hline 8 & Dokter bersedia mendengar keluh kesah pasien. & 406 & 21,60 \\
\hline 9 & Perawat cepat tanggap dalam memberikan pelayanan. & 390 & 20,74 \\
\hline 10 & Staf administrasi cepat tanggap dalam memberikan pelayanan. & 371 & 19,73 \\
\hline & Dimensi Jaminan & & \\
\hline 11 & Dokter selalu melakukan pemeriksaan. & 417 & 20,18 \\
\hline 12 & Dokter selalu memberikan penjelasan tentang penyakit pasien. & 414 & 20,04 \\
\hline 13 & Dokter selalu menjawab pertanyaan pasien. & 411 & 19,89 \\
\hline 14 & Dokter bersikap sopan terhadap pasien. & 419 & 20,28 \\
\hline 15 & Perawat bersikap sopan terhadap pasien. & 405 & 19,60 \\
\hline & Dimensi Empati & & \\
\hline 16 & Dokter mengenal pasien dengan baik. & 353 & 18,49 \\
\hline 17 & $\begin{array}{l}\text { Dokter memberikan pelayanan kepada pasien dengan penuh } \\
\text { perhatian. }\end{array}$ & 388 & 20,32 \\
\hline 18 & $\begin{array}{l}\text { Perawat memberikan pelayanan kepada pasien dengan penuh } \\
\text { perhatian. }\end{array}$ & 382 & 20,01 \\
\hline 19 & $\begin{array}{l}\text { Dokter memberikan perlakuan yang adil bagi semua pasien } \\
\text { tanpa memandang status sosial ekonomi. }\end{array}$ & 397 & 20,80 \\
\hline 20 & $\begin{array}{l}\text { Perawat memberikan perlakuan yang adil bagi semua pasien } \\
\text { tanpa memandang status sosial ekonomi. }\end{array}$ & 389 & 20,38 \\
\hline & Dimensi Bukti Fisik & & \\
\hline 21 & Peralatan medis yang digunakan lengkap. & 357 & 18,65 \\
\hline 22 & Ruang tunggu nyaman. & 355 & 18,55 \\
\hline 23 & Ruang pemeriksaan nyaman. & 377 & 19,70 \\
\hline 24 & Penampilan dokter rapi. & 414 & 21,63 \\
\hline 25 & Penampilan perawat rapi. & 411 & 21,47 \\
\hline
\end{tabular}


Tabel 2 Persentase dan Total Skor Variabel Kualitas Pelayanan Rumah Sakit

\begin{tabular}{clcc}
\hline No & \multicolumn{1}{c}{ Dimensi } & Skor Total & Persentase \\
\hline 1 & Keandalan (reliability) & 1.914 & 19,76 \\
2 & Ketanggapan (responsiveness) & 1.880 & 19,40 \\
3 & Jaminan (assurance) & 2.066 & 21,33 \\
4 & Empati (empathy) & 1.909 & 19,70 \\
5 & Bukti fisik (tangibles) & 1.919 & 19,81 \\
& Total & 9.688 & 100 \\
\hline
\end{tabular}

Tabel 3 Persentase dan Total Skor Loyalitas

\begin{tabular}{clcc}
\hline $\begin{array}{c}\text { No } \\
\text { Item }\end{array}$ & Pernyataan & Skor Total & Persentase \\
\hline 26 & Selalu memanfaatkan poliklinik Rumah Sakit X. & 374 & 20,86 \\
27 & $\begin{array}{l}\text { Akan memanfaatkan pelayanan lain selain poliklinik apabila } \\
\text { suatu saat membutuhkan. }\end{array}$ & 387 & 21,58 \\
28 & $\begin{array}{l}\text { Saya akan merekomendasikan Rumah Sakit X kepada } \\
\text { keluarga/kerabat. }\end{array}$ & 357 & 19,91 \\
29 & $\begin{array}{l}\text { Saya akan menceritakan kebaikan Rumah Sakit X kepada } \\
\text { orang lain. }\end{array}$ & 370 & 20,64 \\
30 & $\begin{array}{l}\text { Saya tidak akan pindah rumah sakit, walaupun rumah sakit } \\
\text { lain menawarkan alternatif. } \\
\text { Total }\end{array}$ & 305 & 17,01 \\
& & 1.793 & 100 \\
\hline
\end{tabular}

Tabel 4 Hasil Uji T Hitung

\begin{tabular}{|c|c|c|c|c|c|}
\hline \multicolumn{6}{|l|}{ Coefficients $^{a}$} \\
\hline \multirow{2}{*}{ Model } & \multicolumn{2}{|c|}{ Unstandardized Coefficients } & \multirow{2}{*}{$\begin{array}{l}\text { Standardized } \\
\text { Coefficients }\end{array}$} & \multirow{2}{*}{$\mathbf{T}$} & \multirow{2}{*}{ Sig. } \\
\hline & Std. Error & Beta & & & \\
\hline (Constant) & 667 & ,766 & & 871 & ,386 \\
\hline Keandalan & ,216 & ,051 & ,249 & 4,199 & , OOO \\
\hline Ketanggapan & 187 & ,051 & 208 & 3,676 & , OOO \\
\hline Jaminan & '234 & , 052 & ,268 & 4,528 & , OOO \\
\hline Empati & ,214 & ,058 &, 257 & 3,679 & , OOO \\
\hline Bukti fisik & 124 & , o56 & 133 & 2,240 & ,027 \\
\hline
\end{tabular}

avariabel dependen: loyalitas pasien

Tabel 5 Hasil Uji F hitung

\begin{tabular}{clclll}
\hline $\begin{array}{l}\text { ANOVA }^{\mathbf{b}} \\
\text { Model }\end{array}$ & Sum of Squares & df & Mean Square & F & Sig. \\
\hline Regression & 830,104 & 5 & 166,021 & 110,804 &, $000^{\text {a }}$ \\
Residual & 140,842 & 94 & 1,498 & & \\
Total & 970,946 & 99 & & & \\
\hline
\end{tabular}

a. Predictors: (constant), bukti fisik, jaminan, ketanggapan, keandalan, empati

b. Variabel dependen: loyalitas pasien 
Untuk mengetahui tingkatan menurut penilian responden dapat dilihat dari diagram tahapan kuartil berikut ini, skor maksimal $=5 \times 5$ item $\times 100$ responden $=2.500$ skor minimal $=1 \times 5$ item $\times 100$ responden $=$ 500 rentang $=2.500-500=2.000$ panjang interval $=$ $2.000 / 5=400$ tingkatan penilaian variabel loyalitas pasien adalah skor tidak baik 500-900, kurang baik 901-1300, cukup baik 1.301-1.700, baik 1.701-2.100, dan sangat baik 2.101-2.500. Total skor hasil penelitian variabel loyalitas pasien Rumah Sakit X sebesar 1.793 sehingga dapat disimpulkan bahwa kualitas pelayanan Rumah Sakit X adalah baik.

Uji T kemudian dilakukan untuk menguji secara parsial apakah variabel reliability $\left(\mathrm{X}_{1}\right)$, responsiveness $\left(\mathrm{X}_{2}\right)$, assurance $\left(\mathrm{X}_{3}\right)$, empathy $\left(\mathrm{X}_{4}\right)$, dan tangible $\left(\mathrm{X}_{5}\right)$ berpengaruh signifikan terhadap loyalitas pasien (Y) di Poliklinik Rumah Sakit. Melalui pengujian ini akan diketahui variabel bebas yang paling dominan memengaruhi variabel terikat.

Dari penjelasan di atas dapat disimpulkan bahwa variabel reliability, responsiveness, assurance, empathy, dan tangible semuanya berpengaruh secara parsial terhadap loyalitas pasien di Poliklinik Rumah Sakit X (nilai t hitung $>\mathrm{t}$ tabel).

Berdasar atas hasil di atas, dari kelima variabel kualitas pelayanan yang paling berpengaruh terhadap variabel loyalitas pasien itu adalah variabel yang mempunyai nilai t hitung yang paling besar. Dari hasil tersebut maka urutan variabel kualitas pelayan yang paling berpengaruh terhadap loyalitas pasien adalah assurance, reliability, empathy, responsiveness, dan tangible.

Uji F kemudian dilakukan untuk menguji apakah variabel reliability $\left(\mathrm{X}_{1}\right)$, responsiveness $\left(\mathrm{X}_{2}\right)$, assurance $\left(\mathrm{X}_{3}\right)$, empathy $\left(\mathrm{X}_{4}\right)$, dan tangible $\left(\mathrm{X}_{5}\right)$ secara bersamasama mempunyai pengaruh yang signifikan terhadap variabel loyalitas pasien (Y) di Poliklinik Rumah Sakit.

Berdasarkan penjelasan di atas dapat disimpulkan pengujian signifikan yang artinya variabel reliability $\left(\mathrm{X}_{1}\right)$, responsiveness $\left(\mathrm{X}_{2}\right)$, assurance $\left(\mathrm{X}_{3}\right)$, empathy $\left(\mathrm{X}_{4}\right)$ dan tangible $\left(\mathrm{X}_{5}\right)$ secara bersama-sama berpengaruh signifikan terhadap loyalitas pasien (Y) di Poliklinik Rumah Sakit X.

Uji koefisien determinasi kemudian dilakukan untuk dapat melihat berapa besar pengaruh dimensi reliability, responsiveness, assurance, empathy, dan tangible (kualitas pelayanan rumah sakit) terhadap loyalitas pasien di Poliklinik Rumah Sakit X yang dapat dilihat dari Tabel 6 berikut ini.
Berdasar atas hasil di atas dipeoleh nilai $\mathrm{R}^{2}=0,855$ untuk mengetahui seberapa besar variabel kualitas pelayanan rumah sakit berpengaruh terhadap loyalitas pasien di Poliklinik Rumah Sakit X dapat digunakan rumus sebagai berikut.

$\mathrm{KD} \quad=\mathrm{R}^{2} \times 100 \%$

$=0,855 \times 100 \%$

$=85,5 \%$

Dengan demikian, kontribusi variabel kualitas pelayanan rumah sakit terhadap loyalitas pasien di Poliklinik Rumah Sakit X sebesar 85,5\%, sedangkan sisanya sebesar $14,5 \%$ variabel loyalitas pasien diberikan oleh faktor lain yang tidak teridentifikasi.

\section{Pembahasan}

Hasil uji serempak dan uji parsial menunjukkan bahwa dimensi reliability, responsiveness, assurance, empathy, dan juga tangible secara bersama-sama maupun parsial berpengaruh signifikan terhadap loyalitas pasien di Poliklinik Rumah Sakit X. Hal ini sesuai dengan hasil penelitian Suryaningrat, ${ }^{7}$ yaitu nilai p kualitas pelayanan sebesar 0,00; lebih kecil dari o,05, disimpulkan bahwa kualitas pelayanan berpengaruh terhadap loyalitas pasien. Penelitian lain menunjukkan simpulan yang serupa, yaitu kepuasan, kepercayaan, dan kualitas layanan berpengaruh terhadap loyalitas pasien. Penelitian oleh Dewi ${ }^{8}$ menyimpulkan bahwa kualitas pelayanan berpengaruh positif terhadap loyalitas pasien yang berarti bahwa semakin baik kualitas pelayanan rumah sakit maka semakin tinggi loyalitas pasien dan juga sebaliknya. Hasil penelitian ini sesuai dengan penelitian yang dilakukan oleh Loke dkk., Mohammad Muzahid, dan Mosahab dkk. dengan simpulan yang serupa. Hal di atas juga sesuai dengan hasil penelitian dari Soekiyono ${ }^{9}$ yang menunjukkan bahwa kelima dimensi kualitas pelayanan yang terdiri atas berwujud, keandalan, ketanggapan, jaminan, dan empati berpengaruh positif secara bersama dan parsial terhadap loyalitas pasien.

Dari beberapa pemaparan hasil penelitian di atas menunjukkan simpulan yang serupa, yaitu kualitas pelayanan berpengaruh terhadap loyalitas pasien. Hal ini sesuai dengan teori, yaitu kualitas berkaitan erat dengan kepuasan yang berkontribusi pada terciptanya loyalitas. Kotler juga menyatakan bahwa kualitas adalah jaminan terbaik atas loyalitas. Kualitas pelayanan yang baik dapat menimbulkan persepsi positif sehingga muncul kepuasan dan loyalitas. ${ }^{4}$

Tabel 6 Uji Koefisien Determinasi

\begin{tabular}{|c|c|c|c|c|}
\hline \multicolumn{5}{|c|}{ Model Summary } \\
\hline Model & $\mathrm{R}$ & $R$ Square & Adjusted $R$ Square & Std. Error of the Estimate \\
\hline 1 & $0,925^{\mathrm{a}}$ & 0,855 & 0,847 & 1,2240602 \\
\hline
\end{tabular}

a Predictors: (constant), bukti fisik, jaminan, ketanggapan, keandalan, empati

${ }^{\mathrm{b}}$ Variabel dependen: loyalitas pasien 
Kualitas jasa, sebagai salah satu contohnya adalah pelayanan kesehatan. Azrul Anwar memberikan definisi kualitas pelayanan kesehatan, yaitu pelayanan kesehatan yang pelaksanaannya sesuai dengan kode etik dan standar pelayanan profesi yang dapat menimbulkan kepuasaan pada rerata pasien. Dilihat dari definisi tersebut, terdapat dua sisi yang dinilai, yaitu pasien (konsumen) dan penyedia pelayanan (produsen). Pasien menentukan dari segi kebutuhan dan keinginan, sedangkan penyedia pelayanan itu menentukan spesifikasi kualitas yang akan diberikan. ${ }^{11}$

Dimensi kualitas pelayanan terdapat lima, yaitu reliabilitas (reliability) yang merupakan kemampuan memberikan pelayanan dengan akurat; daya tanggap (responsiveness) adalah kemampuan personil rumah sakit untuk melayani pasien dengan cepat; jaminan (assurance) berupa kemampuan personil rumah sakit dalam menumbuhkan rasa yakin dan percaya pada pasien; empati (empathy), yaitu kemampuan pihak rumah sakit dalam memberikan perhatian kepada pasien; serta bukti fisik (tangibles) berupa tampilan fisik rumah sakit dan staf. ${ }^{4}$

Kualitas pelayanan yang diberikan rumah sakit dapat memberikan keuntungan bagi rumah sakit tersebut. Pasien yang menerima pelayanan yang berkualitas tentu akan merasa puas sehingga timbul dorongan positif untuk dapat memanfaatkan kembali pelayanan tesebut. Hal ini merupakan ikatan relasi yang menguntungkan antara pasien dan rumah sakit. Rumah sakit dapat memanfaatkan kepuasan pasien untuk terus mengidentifikasi kebutuhan dan keinginan pasien serta meminimalisir hingga meniadakan halhal yang tidak menyenangkan yang dirasakan oleh pasien sehingga tercipta pelayanan yang berkualitas. Beberapa manfaat kualitas, yaitu lebih produktif, harga jasa lebih tinggi, dan loyalitas pasien. ${ }^{10}$

Menurut Oliver, loyalitas adalah komitmen pasien untuk berlangganan atau melakukan pemanfaatan ulang dari suatu jasa secara konsisten, walaupun terdapat pengaruh luar yang dapat berpotensi untuk menyebabkan perubahan perilaku. Terdapat banyak keuntungan yang akan diperoleh rumah sakit jika memiliki pasien yang loyal, antara lain mengurangi biaya promosi karena biaya untuk memasarkan kepada pelanggan baru lebih mahal. Selain itu, pasien dengan suka rela akan mempromosikan rumah sakit tersebut kepada keluarga atau rekannya karena merasa puas. Pasien yang loyal dengan perasaan puasnya akan mudah memaafkan kekurangan-kekurangan yang ada sehingga mengurangi biaya kegagalan, misalnya biaya penggantian dan lain-lain). ${ }^{12}$

Pada penelitian ini kontribusi variabel kualitas pelayanan rumah sakit terhadap loyalitas pasien di Poliklinik Rumah Sakit X sebesar 85,5\%, sisanya sebesar $14,5 \%$ variabel loyalitas pasien diberikan oleh faktor lain yang tidak teridentifikasi. Pasien yang loyal memiliki beberapa karakterisitik, yaitu memanfaatkan jasa secara teratur, memanfaatkan jasa atau membeli produk lain di rumah sakit tersebut selain jasa utama yang digunakan, kebal terhadap produk atau jasa sejenis yang ditawarkan oleh pesaing, dan memberi rekomendasi mengenai rumah sakit tersebut kepada keluarga atau kerabat dengan suka rela. Faktor penentu loyalitas pasien di antaranya adalah kualitas pelayanan seperti hasil penelitian ini, sedangkan faktor lain yang tidak diidentifikasi dalam penelitian ini yang juga dapat menentukan loyalitas pasien adalah input (man, machine, money, market, materials, method) dan output (hasil dari pelayanan yang diberikan kepada pasien)..$^{12}$

\section{Simpulan}

Kualitas pelayanan Rumah Sakit yang terdiri atas dimensi keandalan, ketanggapan, jaminan, empati, dan bukti fisik secara bersama-sama dan parsial berpengaruh terhadap loyalitas pasien di Poliklinik Rumah Sakit X Bandung.

\section{Ucapan Terima Kasih}

Penulis mengucapkan terima kasih kepada Direktur dan staf Rumah Sakit X Bandung serta seluruh responden yang bersedia berpartisipasi sehingga penelitian ini dapat terlaksana.

\section{Daftar Pustaka}

1. Wigati PA. Analisis pengaruh persepsi pasien tentang mutu pelayanan dokter terhadap loyalitas pasien di Poliklinik Umum Instalasi Rawat Jalan Rumah Sakit Panti Wilasa Citarum Semarang tahun 2008. [Online] 2008. [diunduh 21 Juni 2012.] Tersedia dari: http://eprints.undip. ac.id/17893/1/Putri_Asmita.pdf.

2. Phillip K. Manajemen pemasaran. Edisi 13: Jakarta: Erlangga: 2009.

3. Supriadi S. Loyalitas pelanggan jasa: studi kasus bagaimana rumah sakit mengelola loyalitas pelanggannya. Bogor: PT Penerbit IPB Pres: 2011.

4. Lupiyoadi R, Hamdani A. Manajemen pemasaran jasa. Edisi ke-2. Jakarta: Salemba Empat; 2008.

5. Hartono B. Manajemen pemasaran untuk rumah sakit. Jakarta: Rineka Cipta; 2010.

6. Sastroasmoro S. Dasar-dasar metodologi penelitian klinis. Edisi ke-3. Jakarta: CV Sagung Seto; 2008.

7. Suryaningrat D. Hubungan kualitas pelayanan terhadap loyalitas pasien melalui kepuasan sebagai variabel intervening dalam pelayanan kesehatan. J Ilmiah Ibnu Sina. 2018;3(1):115-24. [diunduh 10 April 2019]. Tersedia dari: http://jiis. akfar-isfibjm.ac.id/index.php/JIIS/index.

8. Dewi RR. Pengaruh kualitas pelayanan terhadap loyalitas pasien pengguna BPJS dengan kepuasan pasien sebagai variabel intervening. Daya Saing J Ekonomi Manajemen Sumber Daya. 2016;18 [diunduh 10 April 2019]. Tersedia dari: http:// journals.ums.ac.id/index.php/dayasaing/article/ viewFile/4511/2928

9. Soekiyono S. Analisis faktor yang mempengaruhi kepuasan pasien Badan Pelayanan Jaminan Sosial (BPJS) Kesehatan pada Rumah Sakit Jabodetang. Derivatif J Manajemen. 2017;11(1):50-60. [diunduh 10 April 2019]. Tersedia dari: https:// fe.ummetro.ac.id/ejournal/index.php/JM/ 
article/view/149

10. Tjiptono F. Service, quality \& satisfaction. Edisi ke-4. Yogyakarta: Andi; 2016.

11. Purnama N. Manajemen kualitas perspektif global. Yogyakarta: Ekonisia; 2006.

12. Hurriyati R. Bauran pemasaran dan loyalitas konsumen. Bandung: CV Alfabeta; 2010. 